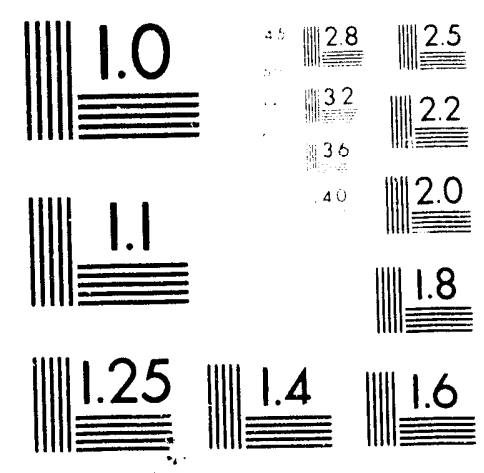



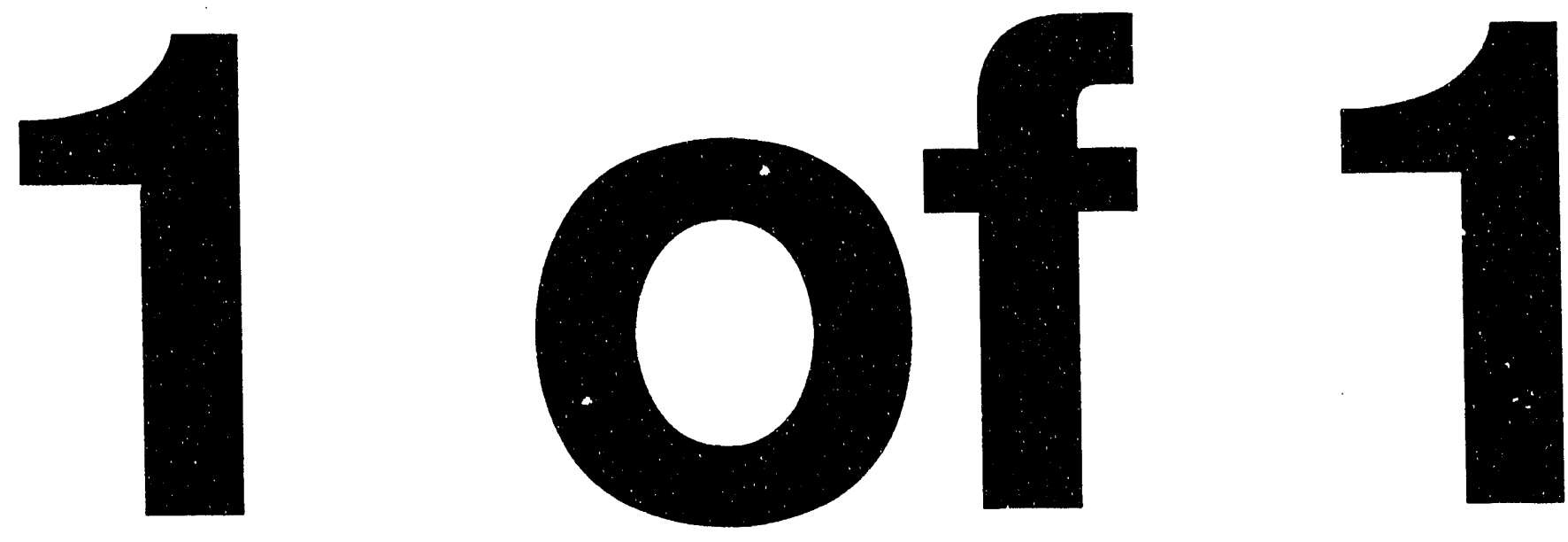
Tennessee

Valley

Authority
Water Managcment

Chattanooga, Tennessee
TVAWM -. 93/22

August 1993

BIOMONITORING OF FISH COMMUNITIES, USING IHE INDEX OF BIOTIC INTEGRITY (IBI) IN RABBIT CREEK -CAT CREEK WATERSHED,

SUMMER 1992

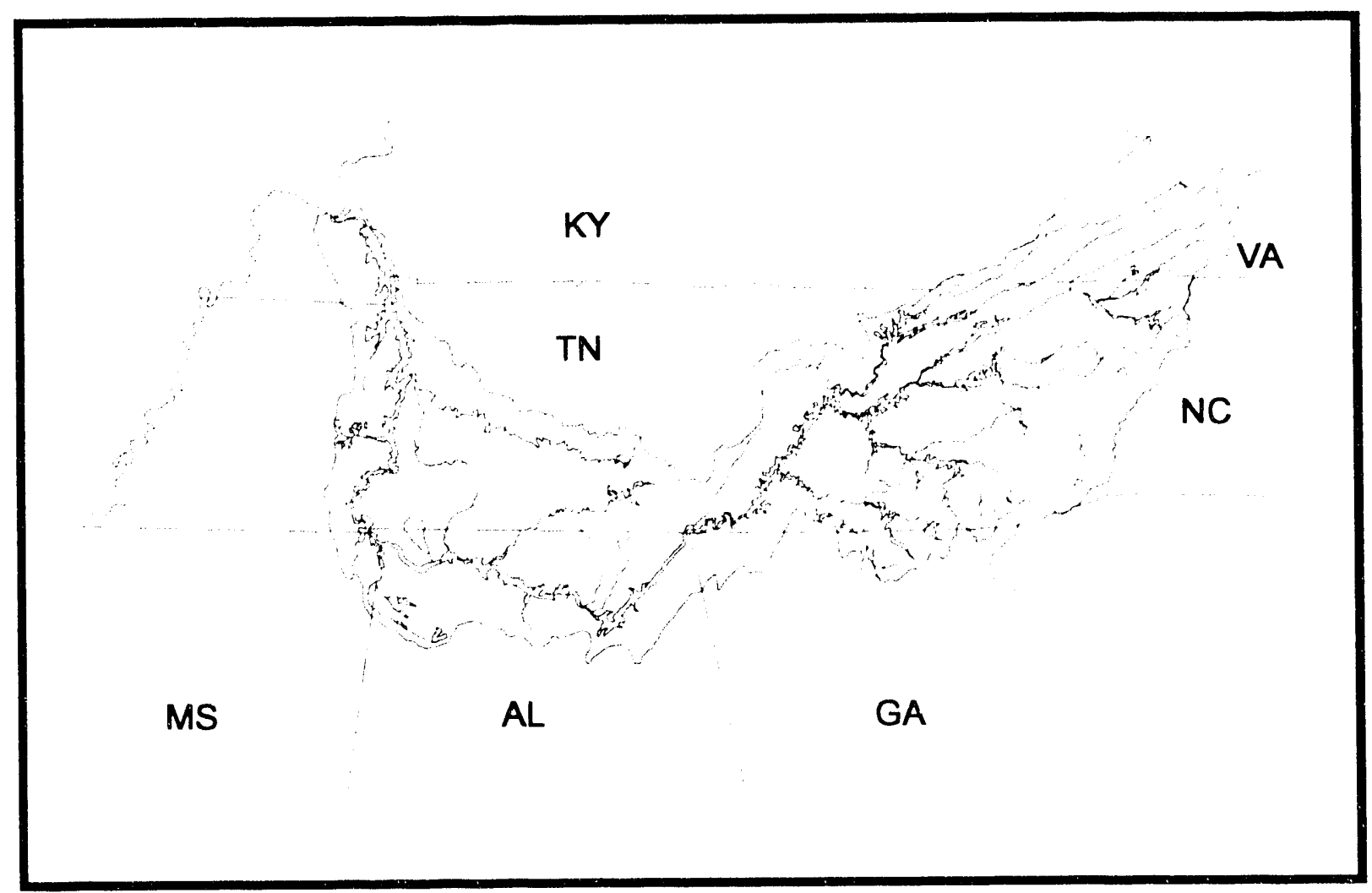

WATER MANAGEMENT

614

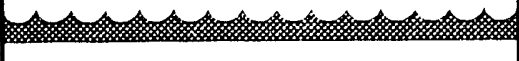


BIOMONITORING OF FISH COMMUNITIES, USING THE INDEX OF BIOTIC

INTEGRITY (IBI) IN THE RABBIT CREEK - CAT CREEK WATERSHED,

SUMMER 1992

Report to: Holly Springs Community Club

Sponsored by: $\quad$ Western North Carolina Alliance

Water Management, TVA

Holly Springs Community Club

Project Director: Dr. William O. McLarney

Field Assistance: Ken MacGregor

Date:

August 17, 1992 
SUMMARY'

The Index of Biotic Integrity (IB!) is a method for evaluating the health of water hodies and watersheds by aralyzing sample catches of fishes. Sites are scored on a numerical scale of 12-60 and on that basis assigned to a "bioclass" ranging from "very poor to "excellent."

During June and July of 1992, five IBI samples were carried out ir the Rabbit Creek watershed (Holly Springs Community). Franklin. North Carolina; four on Rabbit Creek itself, and one on its largest tributary, Cat Creek. The lowermost Rabbit Creek site (site 1) riad been previously sampled in 1990. Site i's IBI score in 1990 was 31.0 (poor); in 1992 it scored 42.1 (fair). Improvements noted were higher catch rate per unit of fishing effort (reflecting higher fish population), a lower percentage of pollution-tolerant species, a higher percentage of specialized insectivores. and one additional pollution-intolerant species. Based on examination of the datu and locally-obtained information on activities in the watershed, the improvement would seem to be due to reduced sedimentation resulting from fencing cattle out of streams.

Nevertheless, lower Rabbit Creek still has problems with a heavy sediment load (due largely to cattle). This is reflected in total absence of darters, few intolerant species, a high percentage of omnivores, generalist feeders and herbivores, low population density, and a high percentage of fish with infectious diseases.

Three $|\mathrm{B}|$ sites (numbers 2, 3, and 4) located further upstream, above the confluence of Cat Creek, showed better $|B|$ scores which were very similar to each other (45.0 - fair-good, 47.5 - good-fair, and 45.0 fair-good, respectively, from the lowermost to the uppermost site). As compared to site 1 , they showed fewer omnivores, generalists, and herbivores, higher population densities, and much lower incidence of disease.

The Cat Creek $|\mathrm{B}|$ site (site 5) had the lowest score of the five sites (40.0 - fair). Cat Creek was characterized by relatively low species diversity, only one pollution-intolerant species, a very high percentage of omnivores, generalists, and herbivores, and a high disease rate. Unlike Rabbit Creek, the diseases seen were of types usually associated with toxic effects, rather than organic pollution. In addition to the organic pollution and sedimentation characteristic of Rabbit Creek, Cat Creek appears to be affected by the presence of the Holly Springs Golf Course in its watershed; the herbicides and pesticides used in turf maintenance are likely sources of the apparent toxic effects observed in the fish.

The effect of Cat Creek and the golf course may influence the lower score of site 1 on Rabbit Creek. as compared with the three sites above the confluence of Cat Creek. However, another factor that must be considered is the lower gradient in the lower reaches of Rabbit Creek, leading to more severe sedimentation effects.

Overall, the major causes of depressed $|B|$ scores in the Rabbit Creek watershed would appear to be: 
1. Urganic pellution, mostly from livestock, but also from agricultural runoff and possible septic tank failures.

2. Sedimentation, priricipally from stream tank damage hy cattle, also possibly from agriculture and construction.

3. Toxic pollution from agrochemicals applied to Holly Springs Golf course and agricultural fields.

4. Warming of water and evaporation loss due to elimination of shade on stream banks and construction of ponds. 
INTRODUCTION

The Rabbit Creek watershed is one of 10 major tributary systems to the Little Tennessee River above Fontana Reservoir. As such, it has been included in an ongoing project (now in its fourth year) focusing on the upper Little Tennessee watershed. The project is sponsored by the Western North Carolina Alliance. funded by Water Management of TVA, directed by Dr. William O. McLarney and staffed largely by local volunteers. The ultimate goal of this project is to produce significant improvement in water and habitat quality in the upper Little Tennessee and its tributaries.

At the end of the 1990 study season, an effort was made to prioritize the 16 major tributary watersheds for purposes of restcration and water quality improvement. The Rabbit Creek watershed was selected as the pilot watershed for the following reasons:

- Low initial water quality--Based on Index of Bintic Integrity (|B|) analysis (described below), water quality in Rabbit Creek rated 15th of the 16 watersheds. (Only lotla Creek was worse.) This translates into ample opportunities for verifiable improvement.

- Convenient size--Tributary watersheds ranged from 4.3 to 93.0 square miles in size. Rabbit Creek drains an area of 10.0 square miles, large enough to be significant, but small enough to be treated as a unit.

- Relationship between the watershed and the human community-For practical purposes, the Rabbit Creek watershed is equivalent to the Holly Springs Community.

- Interest in the community--In a meeting of the Holly Springs Community Club in the fall of 1991 , where I presented the results of the $|\mathrm{B}|$ work, the club demoristrated enthusiasm for enhancing the quality of their streams, and agreed to host the first restoration project in the upper Little Tennessee watershed.

The first step in that project was a more complete study of the Rabbit Creek watershed, including the following components:

- Collection of historical information on the watershed and streams.

- Biomonitoring throughout the watershed based on studies of fish (|B|) and macroinvertebrates.

- Physical examination of streams and the watershed.

This report covers only the $|\mathrm{B}|$ work which was completed in 1992. While completion of the other phases of the first year study will provide a more complete picture, completion of the fish work in midsummer provided a good opportunity to make a progress report to the Holly Springs Community.

ABOUT $|B|$

$|B|$ is a method for evaluating the health of a body of water at a particular point through assessing the community of fishes present. The assumption is that the various species potentially present respond in different ways to different stresses. Through sampling the fishes in a representative stretch of stream and 
assigning numerical values ("metrics") to ine selected data, we can arrive at an iBI number placing the stream somewhere on a scale from 12 (a dead streani) tu 60 (o perfectly natural situation with nn major signs of human-induced disturbance). Table 1 outlines the "Biotic Integrity Classes" described by this system.

The metrics used in this study are briefly described below. (Note that some numbers are omitted from the sequence because these metrics are not employed on streams as small as those found in Holly Springs.) For each site, each metric is ranked as poor. fair, or good. and given a corresponding numerical value, so that the minimum possible score ("poor" for all metrics) will be 12 and the maximum possible score 60.

Table 1. Biotic Integrity Classes Used in Assessing Fish Communities Along With General Descriptions of Their Attributes

\begin{tabular}{||l|l|c||}
\hline \multicolumn{1}{|c|}{ Class } & \multicolumn{1}{|c|}{ Attributes } & IBI Range \\
\hline Excellent & $\begin{array}{l}\text { Comparable to the best situations without influence of } \\
\text { humans; all regionally expected species for the habitat } \\
\text { and stream size, including the most intolerant forms. } \\
\text { are present with full array of age and sex classes; } \\
\text { balanced trophic structure. }\end{array}$ & $58-60$ \\
\hline Good & $\begin{array}{l}\text { Species richness somewhat below expectation, especially } \\
\text { due to loss of most intolerant forms; some species with } \\
\text { less than optimal abundances or size distribution; } \\
\text { trophic structure show's some signs of stress. }\end{array}$ & $48-52$ \\
\hline Fair & $\begin{array}{l}\text { Signs of additional deterioration include fewer } \\
\text { intolerant forms, more skewed trophic structure (e.g., } \\
\text { increasing frequency of omnivores); older age classes } \\
\text { of top predators may be rare. }\end{array}$ & $35-44$ \\
\hline Poor & $\begin{array}{l}\text { Dominated by omnivores, pollution-tolerant forms and } \\
\text { habitat generalists; few top carnivores; growth rates } \\
\text { and condition factors commonly depressed; hybrids and } \\
\text { diseased fish often present. }\end{array}$ & $28-35$ \\
\hline Very Poor & $\begin{array}{l}\text { Few fish present, mostly introduced or very tolerant } \\
\text { forms; hybrids common; disease, parasites, fin damage, } \\
\text { and other anomalies regular. }\end{array}$ & 23 \\
\hline No Fish & \begin{tabular}{l} 
Repetitive sampling fails to turn up any fish. \\
\hline
\end{tabular}
\end{tabular}


Metric 1: Number of native species--In an unimpacted streami, all native species expected for a stream of a given size should be present. As human-caused impacts (pollition, sedimentation, habitat loss. introduction of nonnative species) occur, the more delicate species may drop out. Streams of the size in this study should have 11 or more native species.

Metric 2: Number of darter or sculpin species--Darters and sculpins ("mollycrawbottoms" locally) live mainly on the bottom in rocky riffle areas. They are thus used as indicators of the quality of this portion of the habitat. This metric is omitted on sites draining less than seven square miles, since these small streams are characteristically devoid of darters. On sites draining seven ten square miles, there should be at least three species in this group.

Metric 5: Number of intolerant species-These are the species most sensitive to human-caused disturbance. A stream in excellent condition should have three or more of these species, albeit in reduced numbers. The only intolerants found in the Rabbit Creek watershed were the northern hogsucker and the rosyside ciace.

Metric 6: Proportion of individuals as tolerant species--Tolerants are the species which tolerate human disturbance well. For tolerants we consider their proportion in the community, rather than number of species because, while tolerants are almost always present, a high percentage of tolerants indicates that less tolerant species are being displaced. No more than 10 percent of a healthy fish community should consist of tolerants.

Metric 7: Proportion of individuals as omnivores, generalist feeders, or herbivores--Omnivores and generalists are able to adapt to changes in the food chain by changing their diets, while loss of, for example, a single insect species may eliminate or reduce the number of less adaptable species. The most common omnivores and generalists in the Rabbit Creek watershed are the river chub and the blacknose dace. Herbivores (principally the central stoneroller) are included in this metric because their numbers increase in proportion to fertilization (as from agricultural runoff, livestock, septic tanks, etc.) and increased penetration of sunlight to small streams (caused by removal of shade trees from the banks), both of which enhance the growth of algae on which herbivores feed. No more than 10 percent of a healthy fish community should fall into these categories.

Metric 8: Proportion of individuals as specialized insectivores--Insect-eating species with large mouths (sunfishes, sculpins, etc.) are quite adaptable, but species with smaller mouths (notably the shiners, daces, and darters) may be very restricted in what kinds of insects they can eat or where they can forage. Thus relatively limited damage to a stream may reduce their numbers. At least 45 percent of the catch in a healthy stream should consist of specialized insectivores.

Metric 10: Catch rate--In very general terms "more fish is better" (although heavily fertilized waters often have very high populations of relatively tolerant species). In streams the size of those sampled, one standard unit of fishing effort (sample size of about 400 square feet) should produce 19 fish or more. 
Metric 11: Number of species as smije lithophilic spa:ners. Jume fist? build nests and care for their eggs and young. "Simple lithophits" deposit ther eggs and abandon them to the mercy of the environment. Thus continued survival of these species is an indicator of good environmental quality, especially during the spring high water when most fish spawn. A healthy stream should have at least four species of simple lithophils. Here these include shiners, daces, suckers, darters, and sculpıns.

Metric 12: Proportion of individuals with disease. tumors. fin damage, and other anomalies--Most diseases and parasites are nonlethal and, in small numbers. say nothing about the environment. But like minor ailments in humans, they become more prevalent as the quality of the environment deteriorates. In a healthy stream, less than 2 percent of the total catch should show disease symptoms, parasites, or anomalies.

\section{SAMPLING METHODS}

Fish samples in Rabbit Creek and Cat Creek were taken by blocking off a 200-foot section of stream with nets. Within this segment an effort was made to capture something approaching 100 percent of the fish present (excluding the youngest individuals, hatched during the year of sampling). This was done by use of a backpack electrofisher in conjunction with a 20-foot seine net and hand-held dip nets. The seine was stretched across the creek and the shocker used to stun fish upstream, which drifted down into the seine. The catch of the seine was supplemented by dip netting as the shocker operator moved toward the seine. All fish were released after identification.

Identifications were made, and the project directed by Dr. William O. McLarney. Ken MacGregor operated the shocker. All other labor was provided by volunteers (see appendix 1).

\section{SAMPLING RESULTS}

Nineteen species of fish were taken at least once in Rabbit Creek and Cat Creek (table 2). Additional species which might eventually be taken in the Rabbit Creek watershed include a number of temporary migrants 4 om Lake Emory (common carp, Cyprinus carpio; other species of redhorse, Moxostoma spp.; : hite crappie Pomoxis mnularis; channel catfish lctalurus punctatus; golden shiner Notemigonus crysoleucas, etc.). The water shed once supported three species of trout (the native brook trout. Salvelinus fontinalis and the introduced rainbow trout. Oncorhynchus mykiss, and brown trout, Salmo trutta); trout may yet be found in headwater streams and could extend downstream if water quality improves. A number of other species found in similar sized creeks elsewhere in the upper Little Tennessee watershed are missing from Rabbit Creek. Prominent among them are the mirror shiner. Notropis spectrunculus; gitt 
Table 2. Species of Fish Taken in the Ra'Jbit Creek Watershed, with Commeriti on Their Ecological Niches and Other Characteristics:

Centra! stoneroller (Campostoma anomalum)

River chub (Nocomis micropogon)

Rosyside dace (Clinostomus funduloides)

Whitetail shiner (Notropis galacturus)

Tennessee shiner (Notropis leuciodus)

Blacknose dace (Rhinichthys atratulus)

Longnose dace (Rhinichthys cataractae)

Creek chub (Semotilus atromaculatus)

White sucker (Catostomus commersoni)

Northern hogsucker (Hypentelium nigricans)

River redhorse (Moxostoma carinatum)

Brown bullhead (Iccalurus nebulosus)

Rock bass (Ambloplites rupestris)

Redbreast sunfish (Lepomis auritus)

Green sunfish (Lepomis cyanellus)

Bluegill (Lepomis macrochirus)

Largemouth bass (Micropterus salmoides)

Mottled sculpin (Cottus bairdi)
The only true herbivore :aken.

Omnivore, local name "knottyhead."

Intolerant, specialized insectivore, simple lithophil. This is a subspecies of rosyside dace unique to the Little Tennessee watershed, and being considered for state protection.

Specialized insectivore, simple lithophil. Not characteristically a fish of small streams.

Specialized insectivore, simple lithophil.

Generalist feeder, simple lithophil, characteristic of the smallest streams.

Specialized insectivore, simple lithophil, typically found in the fastest water.

Highly tolerant, omnivore, characteristic of the larger pools in very small streams.

Highly tolerant, simple lithophil, rare in North Carolina portion of Little Tennessee watershed.

Intolerant of pollution (but not sedimentation) simple lithophil.

Simple lithophil, ascends Rabbit Creek from Lake Emory to spawn in spring, only juveniles in Rabbit Creek year-round.

Not native, tolerant, omnivore.

Local name "redeye."

Not native, tolerant, local name "robin."

Highly tolerant.

Local name "brim."

Presence in a stream as small as Rabbit Creek probably indicates escape from a farm pond, although it is native to the Little Tennessee.

Simple lithophil, overall by far the commonest fish in the Little Tennessee watershed, local name mollycrawbottom. 
denter, Percina evides, and Tuckaseigee darter. Etheostoma blennioudes: gutsulli (a subspecies of the greenside darter unique to the Litile Tennessee watershed).

$|B|$ samples were taken at four sites on Rabbit Creek and one on Cat Creek. (See figure 1 for map of sampling sites and appendix 2 for characteristics of the habitat at the five sites.) The macroinvertebrate work will include a greater number of stes. However. $1 B 1$ analysis cannot reliably be employed on sites where the drainage area is less than four square miles.

The initial site used in the $1990|\mathrm{~B}|$ study (site 1) was chosen to provide a measure of water quality exiting the Holly Springs community and entering the Little Tennessee (via Lake Emory). It is located at "river mile 1.0" (1.0 mile above the present mouth of Rabbit Creek) - far enough upstream to minimize the presence of "visitor" fish from Lake Emory which would not be characteristic of Rabbit Creek. This site was sampled on June 26, 1990, and again on June 2, 1992, thus offering an indicator of changes in the Rabbit Creek watershed over a two-year period. Tables 3 and 4 shov..... results.

The most immediately obvious indicator of improvement in Rabbit Creek is the catch rate (metric 10). In 1992, 1.8 times as many fish were taken, with an equal amount of effort, as in 1990. Other indications of improvement are the almost total replacement of the tolerant redbreast sunfish, the great population increase by two specialized insectivores (tennessee shiner and warpaint shiner), and the presence of a second intolerant species (rosyside raze). In regard to the latter (metric 2), note also the increase in numbers of northern hogsuckers (frum 2 to 18). In 1990, 31 young-of the-year hogsuckers were taken (but not counted in the |BI), suggesting the beginnings of a comeback by this species.

What could account for the change? The only significant change in the watershed of which I am aware is the increasing tendency to fence cattle out of streams. This would result in both less organic pollution and less sedimentation (from damage to banks). Metrics 6, 8, and 10 suggest a reduction in sedimentation. Both the tolerant redbreast sunfish and the warpaint shiner are primarily inhabitants of pools, where sedimentation is most strongly felt. However, the redbreast sunfish is very tolerant of sedimentation, whereas the warpaint shiner as a specialized insectivore, requires better pool habitat. An increase in catch rate normally accompanies a reduction in sedimentation. as more clean feeding and spawning habitat is made available in pools and along the shoreline.

There is no such clear indication of reduced organic pollution; in fact, the continuing high percentage of diseased fish (metric 12) and the abundance of omnivores, generalists, and especially the herbivorous central stoneroller (metric 7) suggest that organic pollution remains severe.

The importance of inorganic pollutants of two kinds cannot be ruled out. Chemical fertilizers behave like organic pollutants in some res,pects (especially aftecting metrics 7 and 12). Pesticides and herbicides are normally reflected in elimination of intolerant species (metrics 5 and 6 ) and presence of deformities and tumors (metric 12). These effects were not seen. and diseases observed at site 1 were infectious types usually linked to organic pollution 


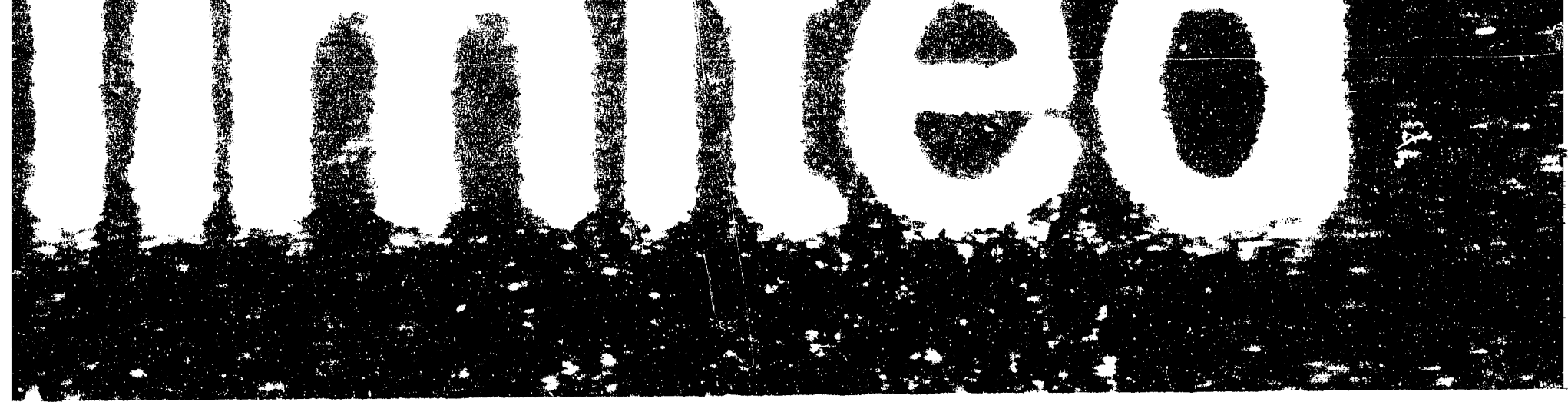

\section{IBI MONITORING SITES IN RABBIT CREEK WATERSHEL}

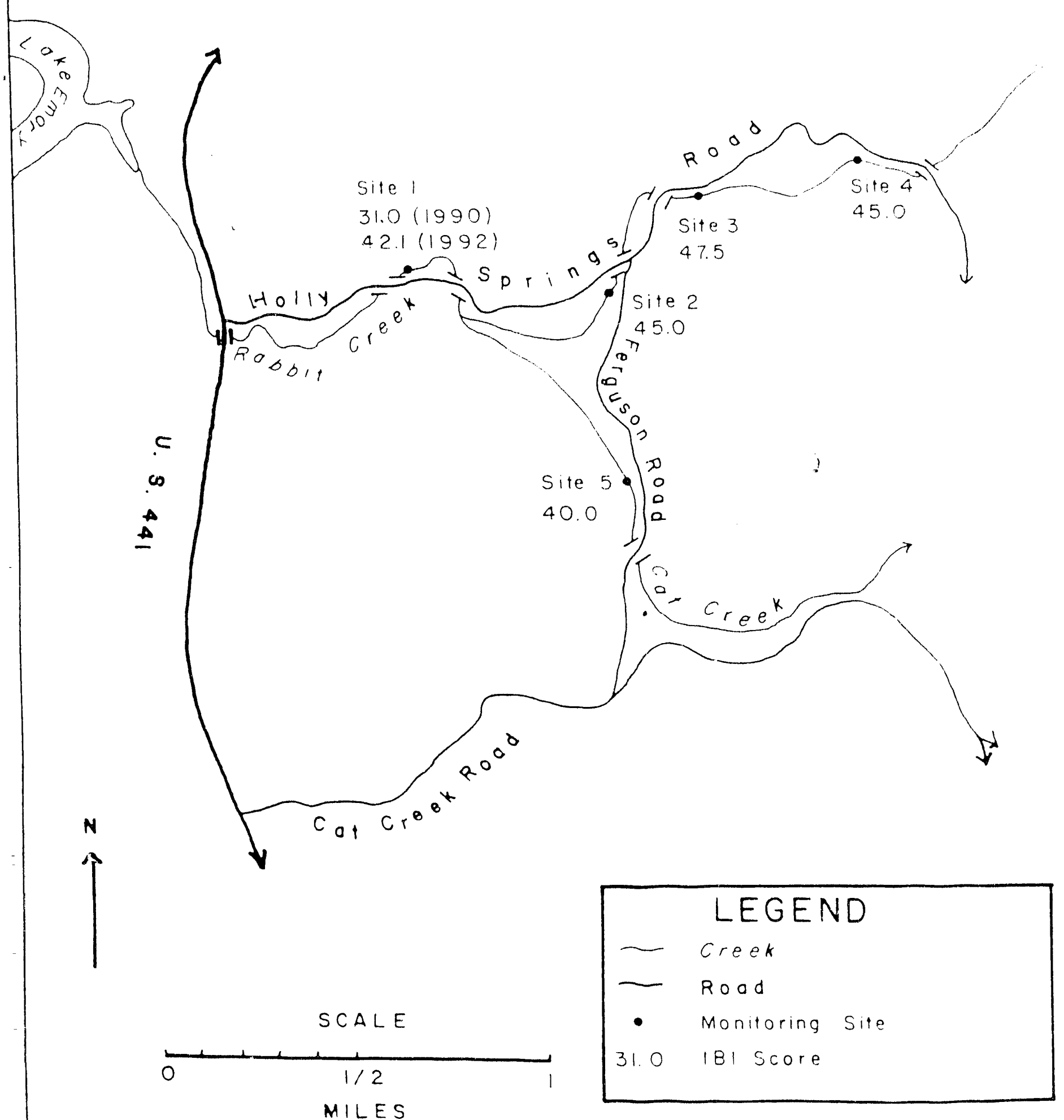


Table 3. Species and Number of Fish Taken at Site 1. Rabbit Creek in 1990 and 1992

\begin{tabular}{|c|c|c|}
\hline SPECIES & $\begin{array}{c}1990 \\
\text { NUMBER }\end{array}$ & $\begin{array}{c}1992 \\
\text { NI JMBER }\end{array}$ \\
\hline Central stoneroller & 7 & 17 \\
\hline River Chub & 14 & 8 \\
\hline Rc syside dace & - & 1 \\
\hline Whitetail shiner & 1 & 1 \\
\hline Tennessee shiner & 2 & 21 \\
\hline Warpaint shiner & 1 & 23 \\
\hline Blacknose dace & 4 & 13 \\
\hline Longnose dace & 1 & 3 \\
\hline Creek chub & 4 & 1 \\
\hline White sucker & - & 5 \\
\hline Northern hogsucker & 2 & 18 \\
\hline River redhorse & 3 & - \\
\hline Brown bullhead & 1 & - \\
\hline Rock bass & 4 & 6 \\
\hline Reroreast sunfish & 15 & 1 \\
\hline 'sluegill & 6 & - \\
\hline Lirgemouth bass & 1 & - \\
\hline Mottled sculpin & 5 & 11 \\
\hline Total & 71 & 129 \\
\hline
\end{tabular}


Table 4. IBI Metrics and Scores, Site 1, Rabbit Creek, 1990 and 1992

\begin{tabular}{|c|c|c|c|c|}
\hline \multirow[b]{2}{*}{ Metric } & \multicolumn{2}{|c|}{1990} & \multicolumn{2}{|c|}{1992} \\
\hline & Total & Score & Total & Score \\
\hline 1. Total number of native species & 14 & 6.7 & 13 & 6.7 \\
\hline 2. Darter and sculpin species & 1 & 4.4 & 1 & 4.4 \\
\hline 5. Number intolerant species & 1 & 2.2 & 2 & 4.4 \\
\hline 6. $\%$ Tolerant species & $28.2 \%$ & 2.2 & $5.4 \%$ & 6.7 \\
\hline $\begin{array}{l}\text { 7. \% Omnivores, generalists, and } \\
\text { herbivores }\end{array}$ & $42.3 \%$ & 2.2 & $34.1 \%$ & 2.2 \\
\hline 8. \% Specialized insectivores & $7.1 \%$ & 2.2 & $38.0 \%$ & 4.4 \\
\hline 10. Catch rate & 7.1 & 2.2 & 12.9 & 4.4 \\
\hline $\begin{array}{l}\text { 11. Number species simple } \\
\text { lithophils }\end{array}$ & 7 & 6.7 & 9 & 6.7 \\
\hline 12. $\%$ With disease or anomalies & $5.6 \%$ & 2.2 & $8.5 \%$ & 2.2 \\
\hline Total & & 31.0 (poor) & & 42.1 (fair \\
\hline
\end{tabular}

There has clearly been improvement in Rabbit Creek between 1990 and 1992, and this suggests hope for further improvement if the effort is made. With an $|B|$ score of 42.1, Rabbit Creek would still rank third-worst among the 16 major upper Little Tennessee tributaries (based on 1990 scores), ahead of lotla Creek and Mud Creek. Problems are reflected especially in the high percentage of omnivores, generalists and herbivores (metric 7), disease rate (metric 12), and the absence of any darter species (metric 2). With respect to darters, it may ultimately be necessary to reintroduce the two or three species that might normally be expected to occur here, since Rabbit Creek is cut off from natural repopulation sources by Lake Emory, which may be impassable to darters.

Site 1 is located well below the confluence of the lowermost tributary of Rabbit Creek (Cat Creek) and thus reflects the influence of that tributary. Remaining sites on Rabbit Creek were chosen to "bracket" other significant tributaries. Thus, site 2 is located between Cat Creek and Elmore Branch, site 3 between Elmore Branch and Ammons Branch, and site 4 between Ammons Branch and Berry Creek and other upstream tributaries. No IBI sites were established above site 4 , since at site 4 the drainage area was 4.0 square miles. Catch data and metrics for these three sites are presented in tables 5 and 6 . 
Table 5. Species and Number of Fish Taken at Sites 2, 3, and 4, Rabbit Creek, 1992

\begin{tabular}{||l|c|c|c||}
\hline Species & $\begin{array}{c}\text { Site 2 } \\
\text { (farthest } \\
\text { downstream) }\end{array}$ & Site 3 & $\begin{array}{c}\text { Site 4 } \\
\text { (farthest } \\
\text { upstream) }\end{array}$ \\
\hline Central stoneroller & 72 & 12 & 9 \\
\hline River chub & 12 & 3 & 2 \\
\hline Rosyside dace & 4 & 7 & 8 \\
\hline Tennessee shiner & 1 & 5 & 1 \\
\hline Warpaint shiner & 2 & 3 & 3 \\
\hline Blacknose dace & 57 & 43 & 35 \\
\hline Longnose dace & 7 & 17 & 7 \\
\hline Creek chub & 3 & 4 & 6 \\
\hline Northern hogsucker & 27 & 17 & 18 \\
\hline Rock bass & 14 & 1 & - \\
\hline Redbreast sunfish & 9 & - & 6 \\
\hline Green sunfish & - & 1 & - \\
\hline Mottled sculpin & 172 & 124 & 124 \\
\hline Total & 380 & 237 & 219 \\
\hline
\end{tabular}


Table 6. IB| Metrics and Scores, Sites 2, 3, and 4, Rabbit Creek, 1992

\begin{tabular}{|c|c|c|c|c|c|c|}
\hline \multirow[b]{2}{*}{ Metric } & \multicolumn{2}{|c|}{ Site 2} & \multicolumn{2}{|c|}{ Site 3} & \multicolumn{2}{|c|}{ Site 4} \\
\hline & Total & Score & Total & Score & Total & Score \\
\hline $\begin{array}{l}\text { 1. Total number } \\
\text { native species }\end{array}$ & 11 & 7.5 & 12 & 7.5 & 10 & 5.0 \\
\hline $\begin{array}{l}\text { 5. Number intol- } \\
\text { erant species }\end{array}$ & 2 & 5.0 & 2 & 5.0 & 2 & 5.0 \\
\hline $\begin{array}{l}\text { 6. \% Tolerant } \\
\text { species }\end{array}$ & $3.2 \%$ & 7.5 & $2.1 \%$ & 7.5 & $5.5 \%$ & 7.5 \\
\hline $\begin{array}{l}\text { 7. \% Omnivores, } \\
\text { generalists and } \\
\text { herbivores }\end{array}$ & $37.9 \%$ & 2.5 & $26.4 \%$ & 2.5 & $23.7 \%$ & 7.5 \\
\hline $\begin{array}{l}\text { 8. \% Specialized } \\
\text { insectivores }\end{array}$ & $1.8 \%$ & 2.5 & $12.8 \%$ & 2.5 & 8.7 & 2.5 \\
\hline 10. Catch rate & 38.0 & 7.5 & 23.5 & 7.5 & 22.2 & 7.5 \\
\hline $\begin{array}{l}\text { 11. Number } \\
\text { species simple } \\
\text { lithophils }\end{array}$ & 6 & 7.5 & 6 & 7.5 & 6 & 7.5 \\
\hline $\begin{array}{l}\text { 12. } \% \text { With } \\
\text { disease or } \\
\text { anomalies }\end{array}$ & $2.4 \%$ & 5.0 & $.0 \%$ & 7.5 & $1.4 \%$ & 7.5 \\
\hline Totals & & $\begin{array}{l}45.0 \\
\text { (fair-good) }\end{array}$ & & $\begin{array}{l}47.5 \\
\text { (good-fair) }\end{array}$ & & $\begin{array}{l}45.0 \\
\text { (fair-good) }\end{array}$ \\
\hline
\end{tabular}


Although the physical habitat was markedly different among these three samples (see appendix 2) water quality as measured by $|B|$ was remarkably uniform, suggesting little effect from Ammons Branch or Elmore Branch. (As an example of habitat effects, notice the tremendous increase in the number of central stonerollers at site 2 , which is completely exposed to the sun.) The only differences in scoring among the three sites were in metrics 1 and 12. The difference in metric 1 may not be significant, since capture of a single green sunfish or rock bass could have bumped the species count up to 11 and the score to 7.5 . The difference in metric 12 probably reflects an increase in organic pollution; while all three sites are affected by cattle in the stream upstream of site 4 , only site 2 was located in a pasture, with constant access to the stream by cattle.

Only one IBI site (site 5) was sampled on Cat Creek, since Cat Creek barely drains 4.0 square miles. Catch data and scores for site 5 are shown in tables 7 and 8.

Table 7. Species and Numbers of Fish Taken At Site 5, Cat Creek, 1992

\begin{tabular}{lc} 
Species & Number \\
\cline { 2 - 2 } Central Stoneroller & 13 \\
River chub & 67 \\
Tennessee shiner & 23 \\
Warpaint shiner & 7 \\
Blacknose dace & 4 \\
Northem hogsucker & 11 \\
Rock bass & 3 \\
Redbreast sunfish & 5 \\
Green sunfish & 1 \\
Mottled sculpin & 6 \\
\multicolumn{1}{c}{ Total } & 140
\end{tabular}

Table 8. Metrics and Scores, Site 5, Cat Creek, 1992

\section{Metric}

1. Total number native species

5. Number intolerant species

5. \% Tolerant species

7. \% Omnivores, generalists, and herbivores

8. \% Speciali- zd insectivores

10. Catch rate

11. Number species simple lithophils

12. $\%$ With disease or anomalies
Total Score

$\begin{array}{ll}9 & 5.0 \\ 1 & 2.5 \\ 4.3 \% & 7.5 \\ 60.0 \% & 2.5 \\ 21.4 \% & 5.0 \\ 20.0 & 7.5 \\ 5 & 7.5 \\ 5.7 \% & 2.5\end{array}$

Total

40.0 (fair) 
Water quality in Cat Creek is significantly lower than at any except the lowermost site on Rabbit Creek. Note especially the elimination of one intolerant species (rosyside dace - me!ric 20) and the high percentage of diseases and anomalies (metric 12). Although not reflected in the score, note also metric 7. In Cat Creek, 60.0 percent of the sample was composed of omnivores, generalists, and herbivores, whereas the corresponding percentages for Rabbit Creek ranged from 23.7 to 37.9 in 1992.

Four factors may negatively influence water quality in Cat Creek:

1. Livestock operations in the upper Cat Creek watershed, leading to sedimentation, organic pollution, and loss of shade, as in Rabbit Creek.

2. Between the $|B|$ site and the Holly Springs Golf Course is an extensive area of beaver ponds which result in warming of water, evaporation loss, and loss of habitat. However, they may also serve as sediment traps, which would be a positive effect on i.ownstream water quality that would partially offset the negative effects of warming and habitat loss.

3. Channelization: The lower reach of Cat Creek, including the $|B|$ site, was straightened for construction of the golf course. This straightening removed all shade from this reach of the creek. This portion of the golf course was never completed, and the lower 0.5 miles of Cat Creek is presently in unfenced pasture.

4. The Holly Springs Golf Course itself: Golf courses generally have a negative impact on streams through:

- fertilizer and herbicide runoff

- erosion and sedimentation from construction

- channelization of streams (in this case including both Cat Creek and tributaries)

- removal of shade trees

- construction of ponds (same effects as beaver ponds, often plus introduction of exotic species)

- increased human population leading to further sedimentation and organic pollution

Most of these factors appear to be present in the case of the Holly Springs Golf Course. While all four of the factors certainly influence water quality in Cat Creek, the particular influence of the golf course and associated channelization is suggested by the absence of the rosyside dace (metric 1) and especially by the proportion of diseased fish (metric 12). Not only was the percentage of disease and anomalies high, the particular anomalies seen were suggestive of chemical pollution. Several fish had one eye blinded, with no evidence of physical injury, and two had tumors.

Note that the lowest IBI score for Rabbit Creek was from site 1, below Cat Creek, and that it is intermediate between the Cat Creek and upper Rabbit Creek scores. It is tempting to ascribe this to the effect of Cat Creek. However, one other factor must be taken into consideration. The portion of Rabbit 
Creek below Cat Creek appears to have a lower gradient than the upper sites. (This is not verifiable from examination of topographic maps, and surveying gear is not available to establish accurate gradients.) Lower stream velocity allows more sediment to accumliate. The low $|\mathrm{B}|$ score at site 1 may reflect this factor and/or the influence of Cat Creek.

\section{RECOMMENDATIONS}

Detailed recommendations should await completion of the other portions of the 1992 study. However, three very general recommendations for improvement can be made at this time:

1. The efforts of the Soil Conservation District and private landowners to fence cattle out of streams should continue.

2. Re-establishment of trees and/or shrubs on stream banks will probably have a positive effect on the fish community.

3. We should be thinking about how to approach the Holly Springs Golf Course once information from the $|B|$ study is supplemented by macroinvertebrate data. 
Appendix 1. Volunteer Participants in the Study (" = Holly Springs Resident)

Amy Carpenter
Adam Cohron
Bunny Cohron
Missy Cohron
- Bill Crawtord
- Nick Crawtord
Rebecca Crawtord
Sam Crawtord
John Fox
Ruth Fox
"Fred Haller
Peggy Huscusson
Scott Imahara
Shawn Johnson
Charley Kaas
Tracy LeFroie
David McCollum
David McCoy
Phillip Moore
Jimmy Nipper
Darryn Norton
Bob Palmer
Dawn Sroka
Newton Tilson
Bob Wadleigh


Appendix 2. Descriptions of the Study Sites

$\begin{array}{lrrrrc}\text { Site No. } & 1 & 2 & 3 & 4 & 5 \\ \text { Date sampled } & & & & & \\ & 6 / 26 / 90 & 7 / 9 / 92 & 6 / 17 / 92 & 6 / 16 / 90 & 7 / 9 / 92 \\ & 6 / 2 / 92 & & & \end{array}$

Landowner RL Pattillo LC Henderson Eleanor Parker Bill Crawtord LC Henderson

$\begin{array}{llllll}\text { Stream mile } & 1.0 & 1.8 & 2.1 & 2.5 & 0.6\end{array}$

Drainage area

(sq mi)

$8.3 \quad 4.8$

4.6

4.0

4.0

Est. gradient

(tt/mi)

$31 \quad 46$

$46 \quad 25$

91

25

Mean width/

range (ft)

$21.4 / 16-27$

$10.1 / 7-17$

13.0/9-16

$12.0 / 6-15$

$6.9 / 5-9$

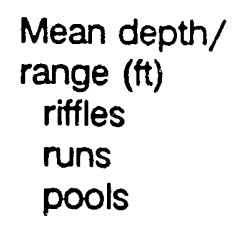

$\begin{array}{ll}11.6 / 5-15 & 5.7 / 5-7 \\ 12.7 / 12-14 & 10.7 / 8-13 \\ 15.9 / 10-24 & 10.0 / 9-11\end{array}$

$9.4 / 7-12$

$10.8 / 8-14$

$7.2 / 6.8$

$12.1 / 7-20$

7.7/7-8

$13 . / 10-18$

$17 . / 14-22$

$8.8 / 7-13$

16./13-19

\section{Substrate}

\section{composition (\%)}

bedrock $\quad 1.5$

boulder -.-

rubble $\quad 34.0$

gravel $\quad 17.1$

sand $\quad 12.2$

silt

35.1

0.1

--
1.3
33.3
11.5
21.8
32.1
---

41.0

$-\cdots$

17.9

19.9

0.1

19.9

-.-

43.9

21.2

4.5

30.3

-..

3.0

40.9

4.5

19.7

31.8

clay 0.1

\% canopy 50

0

100

50

0

Adjacent land
use

residential/ unfenced
forest/road- pasture bank/hayfield

\section{forest/}

roadbank abandoned

field/

forest unfenced pasture 

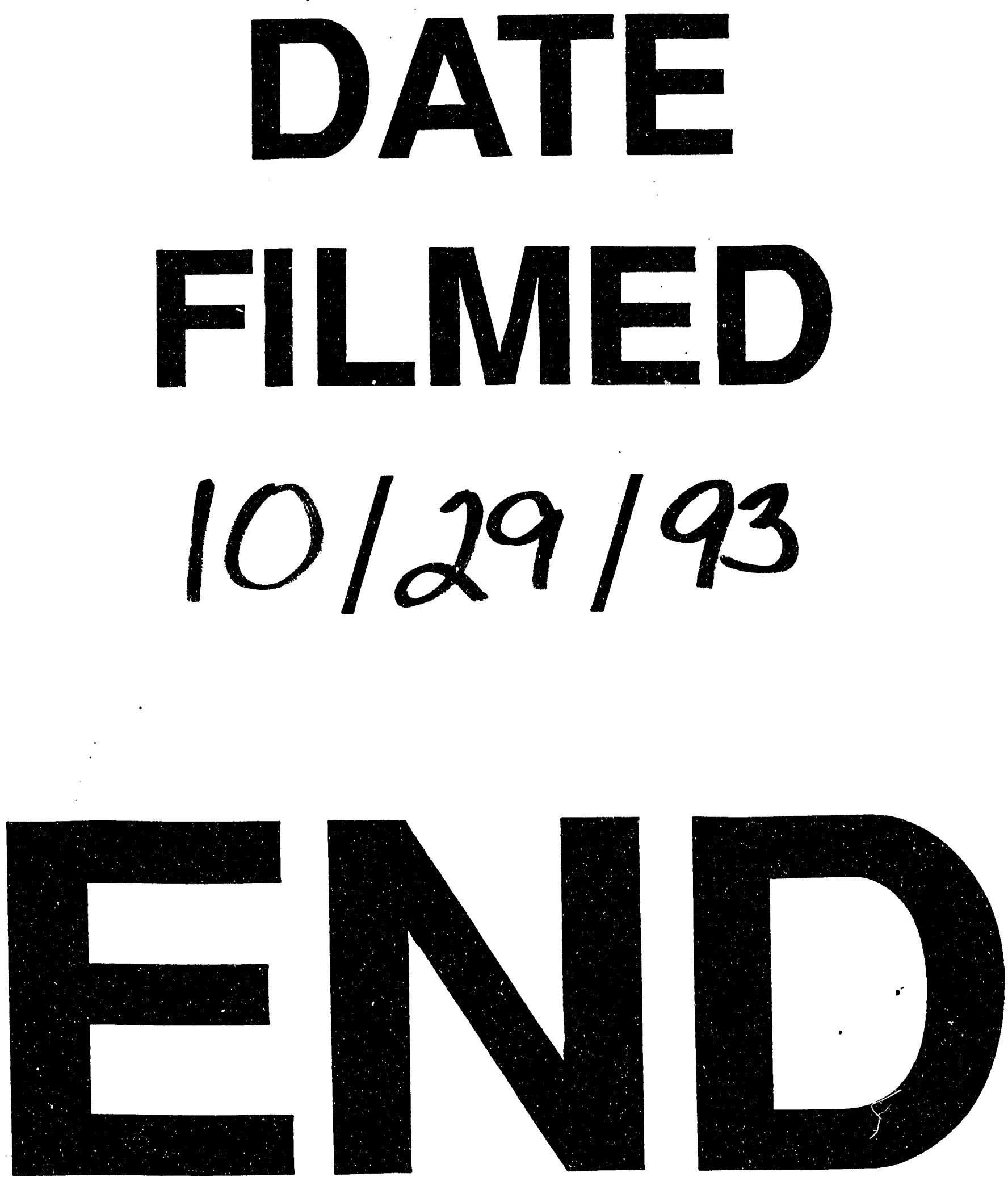
